\title{
INTERFERENCE AND ECONOMIC THRESHOLd LEVEL FOR CONTROL OF Beggartick ON BeAN Cultivars ${ }^{1}$
}

\author{
Interferência e Nivel de Dano Econômico de Picão-Preto sobre Cultivares de Feijão
}

\author{
GALON, L. ${ }^{2}$, FORTE, C.T. ${ }^{2}$, GABIATTI, R.L. ${ }^{2}$, RADUNZ, L.L. ${ }^{2}$, ASPIAZÚ, I. ${ }^{3}$, KUJAWINSKI, R. ${ }^{2}$, \\ DAVID, F.A. ${ }^{2}$, CASTOLDI, C.T. ${ }^{2}$, PERIN, G.F..$^{2}$, RADUNZ, A.L. ${ }^{2}$, and ROSSETTI, J. ${ }^{2}$
}

\begin{abstract}
The aim of the study was to assess the interference and determine the economic threshold level of beggartick damage on bean crops. Treatments consisted of bean cultivars (IPR Uirapuru, BRS Supremo, BRS Campeiro, Fepagro 26, BRS Esplendor and IPR Tuiuiú) submitted to competition with ten beggartick populations. We evaluated plant population, leaf area, ground cover and shoot dry mass of beggartick. Dry mass of shoots of beggartick fitted better to the hyperbolic model, and grain yield losses due to beggartick interference were estimated satisfactorily by this model. BRS Esplendor and IPR Tuiuiú were more competitive than the others in the presence of beggartick. Sowing of BRS Esplendor, IPR Tuiuiu and Fepagro 26 increases the level of economic damage, justifying the adoption of control measures only for higher densities of beggartick. Increase in grain yield, commercial price of beans, herbicide efficiency and reduction in control cost decrease the threshold level for weed control, justifying application of control measures for lower densities of beggartick.
\end{abstract}

Keywords: Phaseolus vulgaris, Bidens pilosa, interference.

\begin{abstract}
RESUMO - Objetivou-se com este trabalho avaliar a interferência e determinar o nível de dano econômico de picão-preto infestante da cultura do feijão. Os tratamentos foram compostos por cultivares de feijão (IPR Uirapuru, BRS Supremo, BRS Campeiro, Fepagro 26, BRS Esplendor e IPR Tuiuiú) e dez populações de picão-preto para cada cultivar. Avaliaram-se as variáveis população de plantas, área foliar, cobertura de solo e massa seca da parte aérea de picão-preto como indicador de infestação. A massa seca da parte aérea do picão-preto apresentou melhor ajuste ao modelo da hipérbole retangular, e as perdas de produtividade de grãos, devido à interferência do picão-preto, podem ser estimadas satisfatoriamente por esse modelo. Os cultivares BRS Esplendor e a IPR Tuiuiú foram os mais competitivos do que os demais na presença do picão-preto. A semeadura dos cultivares BRS Esplendor, IPR Tuiuiú e Fepagro 26 aumentou o nível de dano econômico, justificando a adoção de medidas de controle do picão-preto em densidades mais elevadas. Incremento na produtividade de grãos, no preço do feijão e na eficiência do herbicida e redução no custo de controle diminuem os valores do nivel de dano econômico, o que justifica a adoção de medidas de controle em baixas densidades de picão-preto.
\end{abstract}

Palavras-chave: Phaseolus vulgaris, Bidens pilosa, interferência.

\section{INTRODUCTION}

Among the weeds that infest bean crops, the beggartick is highlighted for the losses caused and by the quantity and quality of the harvested grains (Santos and
Cury, 2011). The losses are aggravated by the broad and the high seed production, when infesting bean crops, and also for the elevated competitive ability presented to the crops by this weed (Santos and Cury, 2011).

1 Recebido para publicação em 23.9.2015 e aprovado em 1.3.2016.

2 Universidade Federal da Fronteira Sul (UFFS), Erechim-RS, Brasil, <leandro.galon@uffs.edu.br>; ${ }^{3}$ Universidade Estadual de Montes Claros Janaúba-MG, Brasil. 
Researches involving the competitive capacity of crops versus weeds allow the development of management strategies, since they can define characteristics that confer a higher competitive ability to crops rather than infesting plants (Vidal et al., 2010; Bressanin et al., 2013; Tavares et al., 2013; Parreira et al., 2014). From the many tools available to study competition between plants in a community, the nonlinear equation of the rectangular hyperbola. This model relates the crop's losses in productivity using the variables population, dry mass, ground cover, and leaf area from the weeds (Agostinetto et al., 2010; Kalsing and Vidal, 2013). The hyperbola model contains parameters ( $i$ and $a$ ) that present biological agronomic meaning, which can be used as a competitiveness rate (Cousens, 1985).

Bean infesting beggartick's management is done almost exclusively by the use of herbicides due to its practicality, efficiency and lower cost, when compared to other control methods. However, at the present time, more sustainable production models are pursued in order to lessen the environmental impact over the agroecosystems, the residue risk in the food and intoxications on the people involved in agricultural activities. With this in mind, the herbicide application based on the concept of economic threshold level (ETL) predicts the use of the seed control method when the damage caused by the weeds is higher than the cost of the control method (Agostinetto et al., 2010; Vidal et al., 2010; Kalsing and Vidal, 2013).

When the ETL is used decision-making for controlling weeds present in farming, the estimated losses on grain production of the crops and the cost for the control options available are compared, providing an analysis of the gain obtained with the control option that was used (Bauer and Mortensen, 1992). In order to estimate the ETL, regression equations or damage functions are usually used, since they relate the crop's losses in productivity with possible control measures for the weeds in its post emergence control (Kalsing and Vidal, 2013).

From the many elements that influence in the competition between weeds and crops, those related to management practice are mentioned, such as, the use of cultivars with higher competitive ability, which can diminish the degree of competition of weed, increasing the ETL and minimizing the need for control measures (Vidal et al., 2010; Kalsing and Vidal, 2013; Parreira et al., 2014). When that information is available, they can hold an important role in the choosing of management methods that depend especially on herbicides, for a system aimed in the ecophysiological knowledge (Bauer and Mortensen, 1992), and, in this way, a more sustainable model of bean infesting weeds control is obtained.

The research's hypothesis was that the loss in productivity of type black beans caused by interference of beggartick varies with the weed's population and the different crops evaluated, and can be quantified with mathematical models that allow the establishment of damage levels to the crop. The objective of this research was to evaluate the interference and determine the economical threshold level of infesting beggartick in bean crops.

\section{MATERIAL AND METHODS}

The experiment was conducted in the field, in Quatro Irmãos, Rio Grande do Sul State, on the agricultural year of 2012/13, being the soil classified as Haplic Ta Eutrophic Cambisol. The maintenance fertilization was conducted according to physical-chemical analyses and following the recommendations for the black bean crop (CTSBF, 2012).

The adopted crop method was the direct planting in straw, under haystacks formed by black oat, drying the area with glyphosate (1,080 $\mathrm{g} \mathrm{ha}^{-1}$ of acid equivalence) before the seeding. The adopted experimental outlining was the completely randomized, without repetitions. Each experimental unit (portion) was composed by $14.1 \mathrm{~m}^{2}(2.82 \times 5.0 \mathrm{~m})$ area, being the seeding conducted in six lines of $5 \mathrm{~m}$ long and separated by $0.47 \mathrm{~m}$; the seeding was done in $15 / 11 / 2012$. The sowing density of the bean cultivars was 12 viable seeds for square meter or approximately 250,000 seeds ha ${ }^{-1}$ (CTSBF, 2012).

The treatments were constituted of six black beans cultivars (IPR Uirapuru, BRS 
Supremo, BRS Campeiro, Fepagro 26, BRS Esplendor and IPR Tuiuiú) and ten populations of beggartick $(0,2,2,2,4,6,12,14,52$ and 58; $0,4,8,14,22,24,28,38,40$ and $44 ; 0,8,14$, $14,24,24,36,42,42$ and $54 ; 0,2,6,14,20,22$, $22,30,34$ and 60; 0, 6, 8, 16, 18, 28, 30, 40, 40 and $50 ; 0,2,8,8,16,20,20,28,34$ and 50 plants $\mathrm{m}^{-2}$ ) for each tested cultivar, respectively. Since the beggartick is derived of the soil seed bank, the establishment of the populations was variable, since factors as infestation, vigor, humidity, and others, prevent the establishment of the exact desired number of plants in each treatment (experimental unit). The populations of weeds were established from the soil seed bank, by the application of the herbicide fluazifop-Pbutyl + fomesafen $\left(250+250 \mathrm{~g} \mathrm{ha}^{-1}\right)+$ mineral oil $\left(\right.$ Energic $\left.^{\circledR}-0.2 \% \mathrm{v} / \mathrm{v}\right)$, when the crop had four trefoils and the weeds had three to six leaves. The period was chosen for being the most suitable for the application of herbicides in post emergence. The beggartick plants were protected with plastic cups, in order to not be harmed by the herbicide. The other remnant weeds in the experimental units, which were not part of the experiment, were controlled by weeding.

When the bean had reached stage V3, nitrogenous coverage was applied in the form of urea, according with the chemical analyses of the soil and with the expectative of crop efficiency.All the remnant utilized management practices were those recommended by research for black bean crop (CTSBF, 2012).

The quantification of plant population (PP), leaf area (LA), ground coverage (GC) or dry mass of the aerial parts (DM) of beggartick was done 41 days after the emergence (DAE) of the crop. To determine the PP variable, the plants present in two areas of $0.25 \mathrm{~m}^{2}$ $(0.5 \times 0.5 \mathrm{~m})$ were counted in each portion. The quantification of the LA of the competitor plant was made with a portable electronic leaf area integrator, model CI-203, from CID BioScience, measuring all the plants in an area of $0.25 \mathrm{~m}^{-2}$ for each portion. The SC by beggartick plants was visually evaluated, individually, by two evaluators, using percentage scale in which the value zero corresponds to the absence of SC and a value of 100 represents full coverage of the soil. The DM of the beggartick $\left(\mathrm{g} \mathrm{m}^{-2}\right)$ was determined by the gathering of the plants inside an area of $0.25 \mathrm{~m}^{2}$ per portion and dried in forced air circulation oven at the temperature of $60 \pm 5{ }^{\circ} \mathrm{C}$, until it reached a constant mass.

The quantification of the bean grains productivity was obtained by the harvest of the plants in usable area of $5.64 \mathrm{~m}^{2}$ of each experimental unit, when the humidity level of the grains reached approximately $18 \%$. After weighing the grains, its humidity was determined and, subsequently, the masses were standardized to $13 \%$ of humidity. With the data of the grain productivity, the loss percentage was calculated in relation to the portions maintained without infestation (control), according with Equation 1:

$$
\operatorname{Loss}(\%)=\left(\frac{R a-R b}{R a}\right) \times 100
$$

where: $R a$ and $R b$ : productivity of the crop without or with the presence of competitor plants (beggartick) respectively.

Previously to the analysis of the data, the values of DM $\left(\mathrm{g} \mathrm{m}^{-2}\right)$, SC (\%) or LA $\left(\mathrm{cm}^{2}\right)$ were multiplied by 100 , making the correction factor of the model not necessary (Agostinetto et al., 2010).

The relations between percentage losses in the productivity of the beans according to the explanatory variables were separately calculated for each cultivar, utilizing the linear regression model derived from rectangular hyperbola, proposed by Cousens (1985), according to Equation 2:

$$
P p=\frac{(i * X)}{\left(1+\left(\frac{i}{a}\right) * X\right)}
$$

where: $P p=$ productivity loss $(\%) ; X=$ beggartick population, dry mass of the aerial part, leaf area or ground coverage; $i$ and $a=$ losses in productivity (\%) per unit of beggartick plants when the variable value is close to zero and when it tends to infinite, respectively. For the calculation procedures, the Gauss-Newton method was used, in which, with successive 
iterations, estimates the parameter values, in which the sum of the squared deviations of the observations, in relation to the adjusted values, are minimum (Ratkowsky, 1983). The value of the $F$ statistic $(p \leq 0,05)$ was used as an analysis criteria for the data adjustment to the model. The acceptance criteria of the adjustment of the data to the model was based in a greater values of the determination coefficient $\left(\mathrm{R}^{2}\right)$ and in the smallest value of the residuo average square (RAS).

In order to calculate the economic threshold level (ETL), estimates of the parameter $i$ obtained through Equation 2 were used (Cousens, 1985) and the adapted equation of Lindquist and Kropff (1996) - Equation 3:

$$
E T L=\frac{(C c)}{\left(R^{*} P^{*}\left(\frac{i}{100}\right) *\left(\frac{H}{100}\right)\right)}
$$

where: $E T L=$ economic threshold level (plants $\mathrm{m}^{-2}$ ); $C c=$ controle cost (herbicide and tractorized terrestrial application, in dollars ha $\left.{ }^{-1}\right) ; R=$ black beans grain productivity (kg ha ${ }^{1}$ ); $P=$ black beans price (dollars kg-1 of grains); $i=$ loss (\%) in productivity of black bean per unit of competitive plant when the population level is close to zero; and $H=$ herbicide's efficiency level (\%).

For the variables $\mathrm{Cc}, \mathrm{R}, \mathrm{P}$ and $\mathrm{H}$ (Equation $3)$, three values that occurred in the last 10 years were estimated. Thus, for the control cost $(\mathrm{Cc})$, the average price was considered, and the maximum and minimum costs altered in $25 \%$, in relation to the average cost. The bean grain production (R) was based in the smallest (668 $\left.\mathrm{kg} \mathrm{ha}^{-1}\right)$, average (1.084 $\left.\mathrm{kg} \mathrm{ha}^{-1}\right)$ and biggest $\left(1,341 \mathrm{~kg} \mathrm{ha}^{-1}\right)$ obtained in Rio Grande do Sul in the last 10 years. The product price $(\mathrm{P})$ was estimated from the smallest (US\$ 15.90 for the $60 \mathrm{~kg}$ sack), average (US\$ 36.70 for the $60 \mathrm{~kg}$ sack) and biggest (US\$ 62.20 for the $60 \mathrm{~kg}$ sack) prices of black beans paid per $60 \mathrm{~kg}$ sack in the last 10 years. The values for the herbicide efficiency $(\mathrm{H})$ were established in the order of 80,90 and $100 \%$ of control, where $80 \%$ is the minimum control considered effective in the weed. In the ETL simulations, the intermediate values for the variables that weren't the object of the calculation were used.

\section{RESULTS AND DISCUSSION}

The beggartick explanatory variables PP, LA, GC and DM, for all the evaluated crops, present significant values of $\mathrm{F}$-statistics (Figures 1, 2, 3 and 4). The results show that for the bean crops - type black (IPR Uirapuru, BRS Supremo, BRS Campeiro, FEPAGRO 26, BRS Esplendor and IPR Tuiuiú), the rectangular hyperbola model adjusted properly to the data, presenting $\mathrm{R}^{2}$ values over 0.61 and low RAS, which characterizes an elevated adjustment from the data to the model.

It was determined, on the whole, for most of the evaluated variables, that the estimated values for the $i$ parameter tend to be smaller in the BRS Esplendor, IPR Tuiuiú and Fepagro 26 cultivars, while the smaller competitiveness was verified to the IPR Uirapuru cultivars, for the variable PP, and BRS Supremo cultivars, for GC and DM, which presented the biggest losses in grain productivity when compared to the others (Figures 1, 2, 3 and 4). Many researches have reported the existence of differentiation among cultivars in their competitive ability in crops when in presence of weeds, fact that is attributed to the group of morphophysiological characteristics inherent to them (Barroso et al., 2010; Vidal et al., 2010; Kalsing and Vidal, 2013; Parreira et al., 2014).

An average loss of $14.04 \%$ in the productivity of beans cultivars studied for the LA variable $\left(25 \times 10^{3} \mathrm{~cm}^{2} \mathrm{~m}^{-2}\right)$; BRS Supremo and BRS Esplendor, respectively, were the ones which presented the smallest and biggest loss (10.06 and $16.01 \%)$ in comparison to the others. Although, when the bean plant was analyzed in relation to the biggest LA $\left(100 \times 10^{3} \mathrm{~cm}^{2} \mathrm{~m}^{-2}\right)$, it was determined that the cultivars with the biggest and smallest losses was, respectively, IPR Uirapuru $-34.13 \%$ and BRS Campeiro - $14.28 \%$ (Figure 2). It can be inferred that the cultivars competition degree, in relation to the beggartick, is influenced by the leaf area of the weed, according to what was determined by Parreira et al. (2014), when evaluating the competition between bean cultivars (type carioca) and weeds.

The results for the loss of productivity of the bean cultivars, in relation to the ground coverage percentage (Figure 3 ), show 

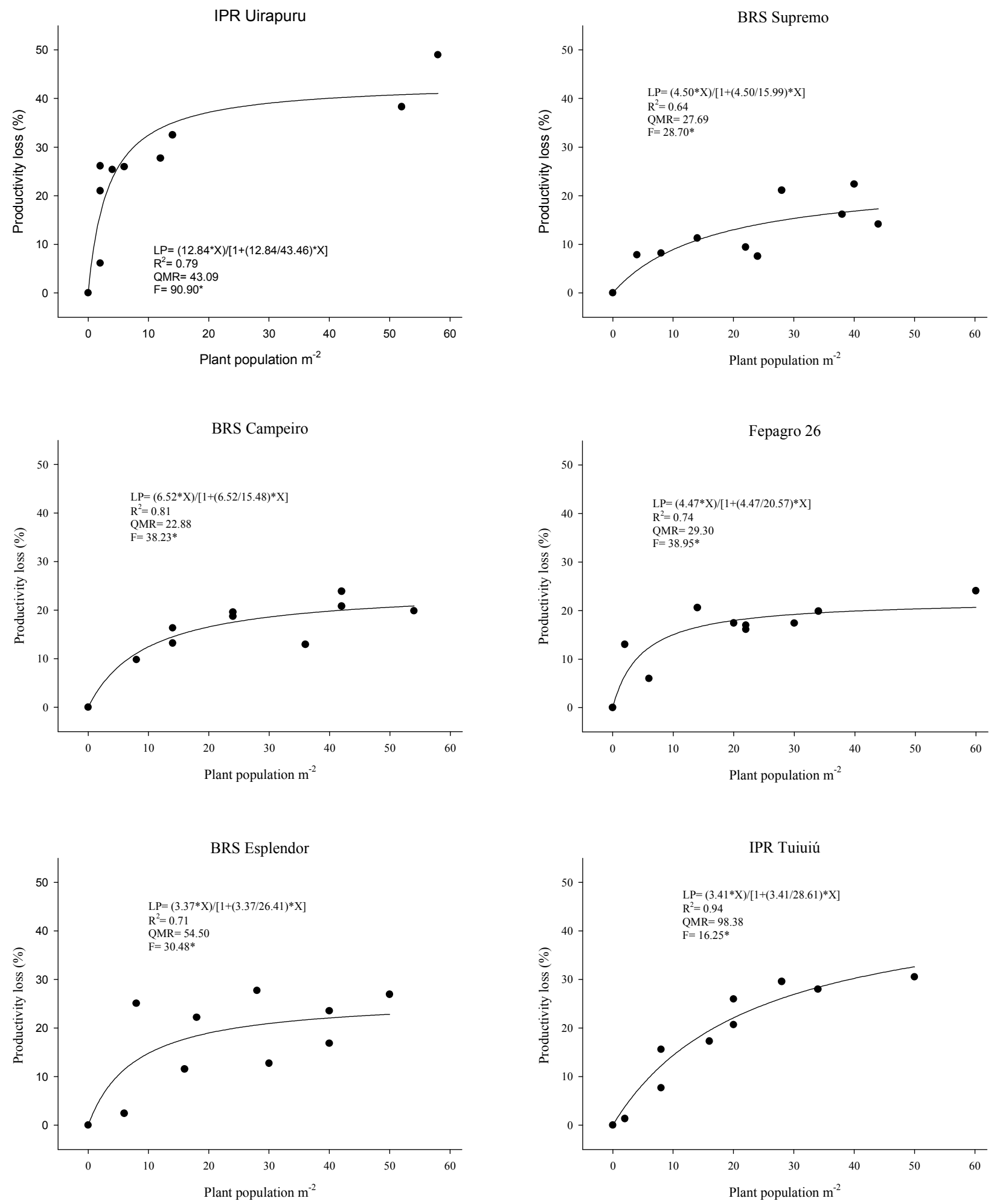

$\mathrm{R}^{2}=$ determination coefficient; QMR: average square of residue; * Significant in $\mathrm{p} \leq 0,05$.

Figure 1 - Loss of productivity (LP) of bean plant cultivars relating to beggartick's population 41 days after emergency. UFFS, Erechim/RS. 

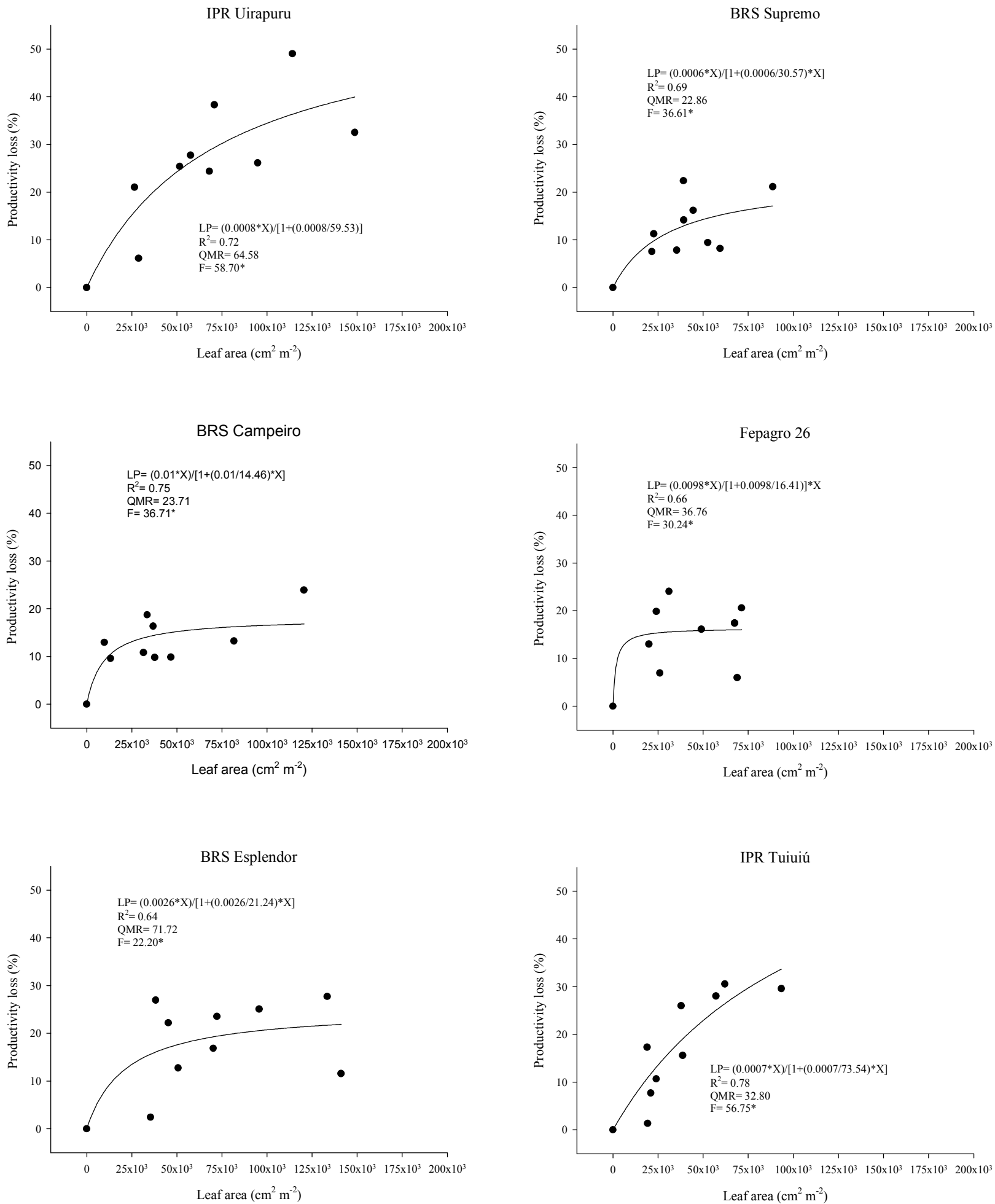

$\mathrm{R}^{2}=$ determination coefficient; QMR: average square of residue; * Significant in $\mathrm{p} \leq 0,05$.

Figure 2 - Loss of productivity (LP) of bean plant cultivars relating to beggartick's leaf area 41 days after emergency. UFFS, Erechim/RS. 

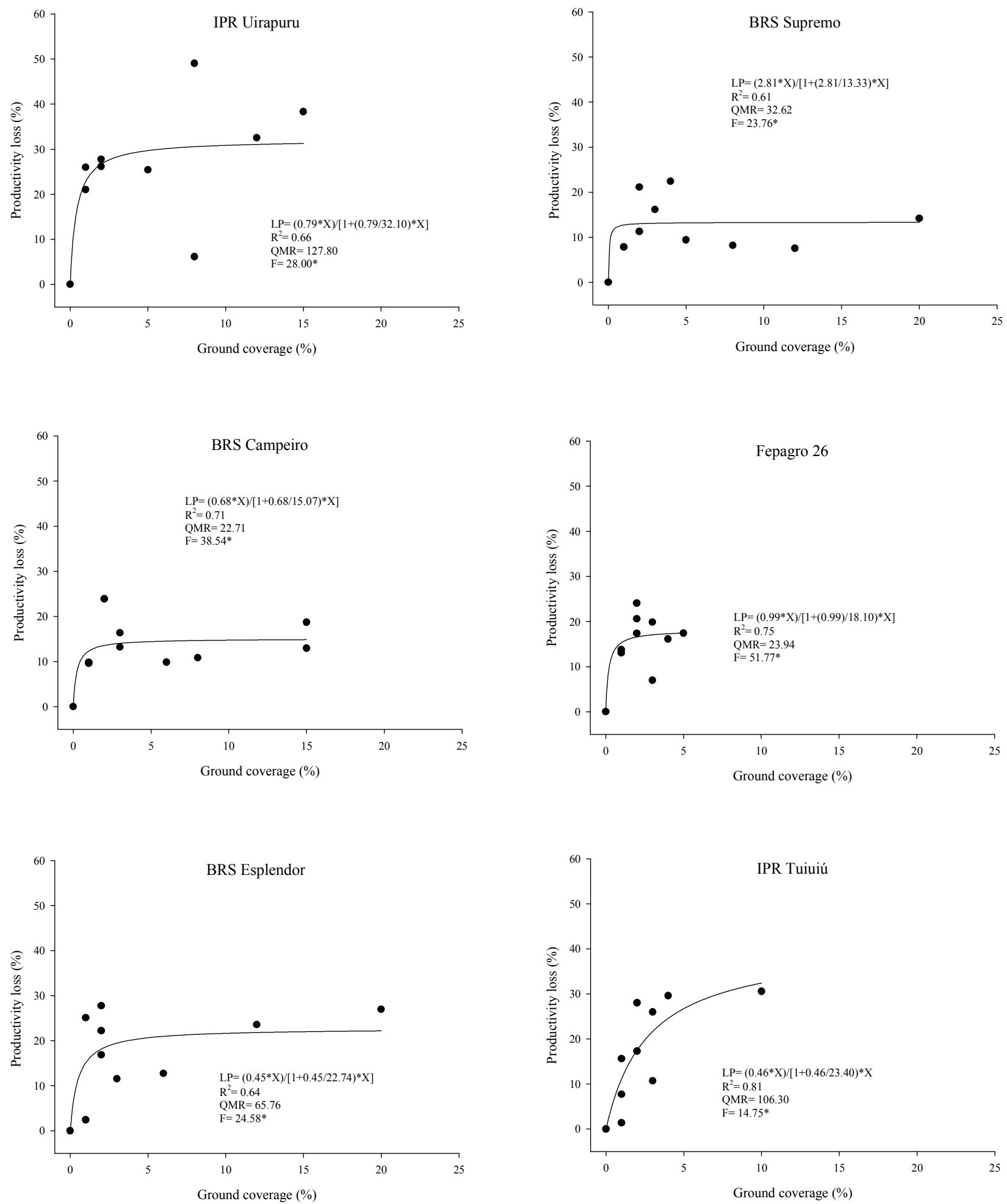

$\mathrm{R}^{2}=$ determination coefficient; QMR: average square of residue; * Significant in $\mathrm{p} \leq 0,05$.

Figure 3 - Loss of productivity (LP) of bean plant cultivars relating to beggartick's ground coverage 41 days after emergency. UFFS, Erechim/RS. 

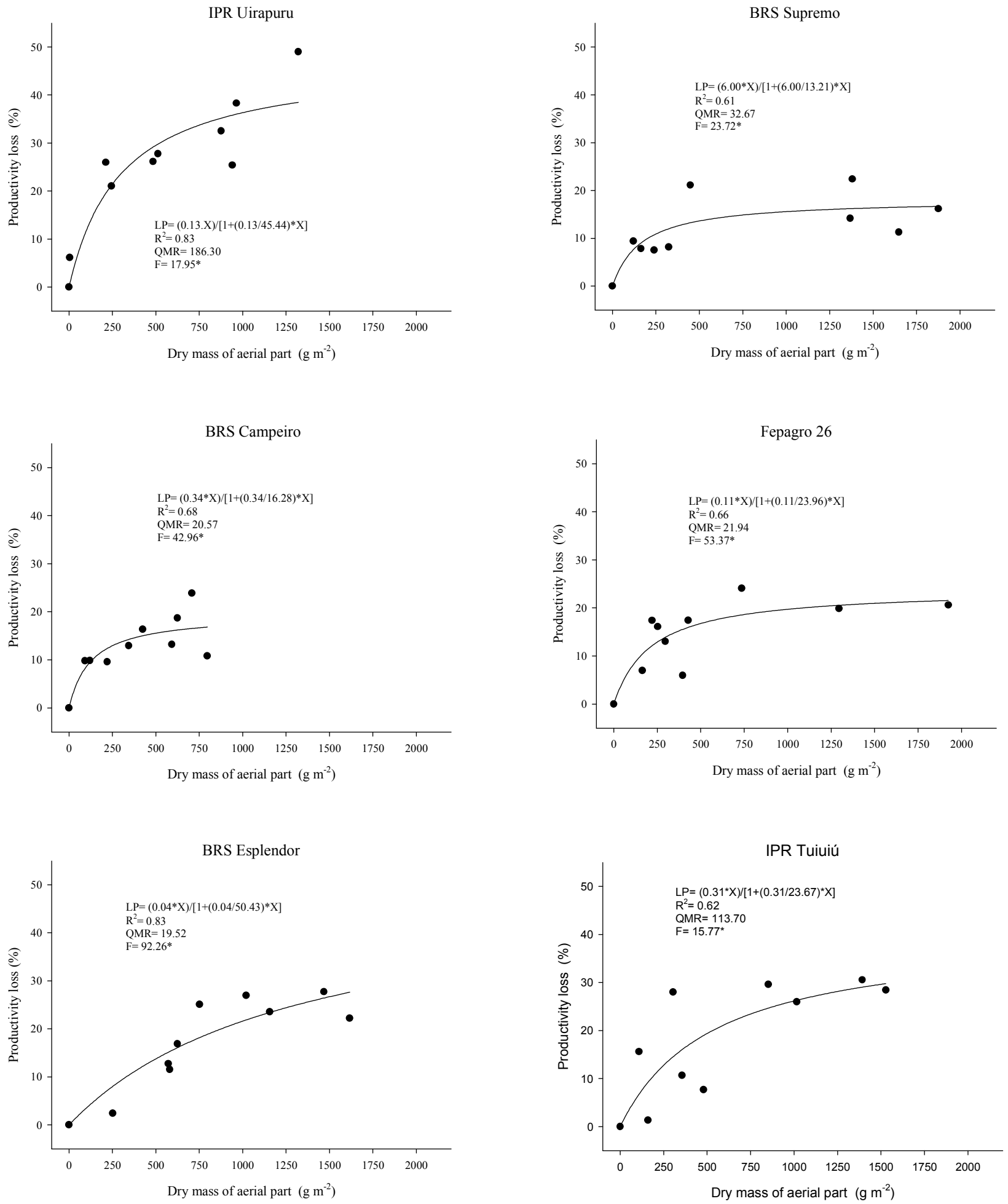

$\mathrm{R}^{2}=$ determination coefficient; QMR: average square of residue; * Significant in $\mathrm{p} \leq 0,05$.

Figura 4 - Loss of productivity (LP) of bean plant cultivars relating to beggartick's dry mass 41 days after emergency. UFFS, Erechim/RS 
similarity to the ones observed in relation to the plant population (Figure 1). It can be implied that, except in IPR Tuiuiú (Figure 3), the other cultivars had already presented the biggest percentage reductions in productivity when $5 \%$ of the ground was covered with beggartick.

In accumulating $100 \mathrm{~g} \mathrm{~m}^{-2}$ of dry mass, the beggartick caused reductions in the beans productivity of $10.10,12.93,11.01,7.54,3.71$ and $13.42 \%$, respectively, for the IPR Uirapuru, BRS Supremo, BRS Campeiro, Fepagro 26, BRS Esplendor and IPR Tuiuiú cultivars (Figura 4).

Kalsing and Vidal (2013) also determined that bean cultivars, when competing with alexander grass, show a distinct behavior and related this with the intrinsic characteristics that they show, as already stated. Other authors also state that there are differences between bean cultivars in competition with weeds. Barroso et al. (2010) and Parreira et al. (2014) attribute this fact to characteristics such as growth habit, development cycle and number of branches, among others, that affect the competitive ability of the crop, which causes differentiation between the cultivars involved in competition with weeds.

Being the $i$ parameter an index used to compare the relative competitiveness between species (Swinton et al., 1994), differentiated values were observed for the bean plant cultivars in the tested explanatory variables (Figures 1, 2, 3 and 4).

The comparison between cultivars considering the $i$ parameter, on the average of the four explanatory variables (PP, GC, LA and $\mathrm{DM})$, demonstrated that the rank, on the whole, in relation to competitiveness was: BRS Esplendor > IPR Tuiuiú > Fepagro $26>$ BRS Campeiro > BRS Supremo > IPR Uirapuru (Figures 1, 2, 3 e 4). The differences in the cultivars results are due to, largely, to their genetic characteristics, or the occurrence of a high standard error in the estimate of the $i$ parameter, and it can be attributed to the variability associated to field experimentation and/or to the phenotypic plasticity of the crop (Dieleman et al., 1995). The result of the present study are corroborated by those from Kalsing and Vidal (2013), which verified that common bean plant cultivars responded in a distinct way over the evaluated parameters when infested by alexander grass.

The estimates of the a parameter, regardless of the explanatory variable, were all inferior to $100 \%$ (Figures 1, 2, 3 and 4), showing that it was possible to properly simulate the maximum losses of bean productivity in bean plants with the used beggartick populations. It can be highlighted that the bigger the productive potential of the crops, the smaller is the daily percentage loss caused by a specific weed species, depending if the soil fertility, the water availability and luminosity are adequate (Kalsing and Vidal, 2013).

For the cultivars in the same growth cycle, it was observed that the explanatory variables presented differentiated $i$ parameters (Figures 1, 2, 3 and 4). In a similar manner, Kalsing and Vidal (2013) determined that cultivars in the same cycle showed different competitiveness, being expressed by the parameter $i$. These authors state that it occurs, among other things, due to a difference in productivity that the cultivars present, which causes a smaller loss of efficiency per individual weed. That corroborates with this study's result, in which the cultivar BRS Esplendor presented the smaller loss in productivity; however, it was the one which showed the smallest grain yield (1.6 ton ha-1) when compared to IPR Uirapuru, BRS Supremo, BRS Campeiro, Fepagro 26 and IPR Tuiuiú, with productivity of 1.8, 2.1, 2.4, 1.9 e 2.1 ton ha ${ }^{-1}$ respectively.

The comparison between the explanatory variables for all the bean cultivars, in general, has shown a better adjustment to the model for the variables $\mathrm{DM}>\mathrm{LA}>\mathrm{PP}>\mathrm{GC}$, considering the biggest average values of $R^{2}$ and the smallest average values of RAS (Figures 1, 2, 3 and 4), showing, in this way, that the DM can be used as a substitute to the variable PP.

The simulation of the economic threshold level (ETL) values was done using the beggartick's explanatory variable PP, since it's the most used in experiments with this objective (Agostinetto et al., 2010; Vidal et al., 2010; Kalsing and Vidal, 2013).

The success in the management system's implementation for the infesting beggartick in bean crops may occur due to the determination in the population that exceeds 
the ETL. In this way, it was observed that BRS Esplendor and IPR Tuiuiú cultivars (normal and medium cycle) showed bigger values of ETL in all carried simulations, varying from 2.20 to 8.72 plants $\mathrm{m}^{-2}$ (Figures 5, 6, 7 and 8). The smallest values of ETL were obtained with the IPR Uirapuru cultivars, with variations of 0.59 and 2.29 plants $\mathrm{m}^{-2}$ (Figures 5, 6, 7 and 8). The other bean cultivars (BRS Supremo, BRS Campeiro and Fepagro 26) were in intermediate levels of ETL.

The factors that made the cultivar IPR Uirapuru present a smaller ETL may be due to a smaller index of leaf area and the growth of only a few lateral branches, those being short, besides the smaller plant stature and the shrubby growth habit (CTSBF, 2012), which allows a greater light entry in the soil and, consequently, a greater growth of the beggartick. The results found by Parreira et al. (2014) corroborates this study, which has observed that the bean cultivars with the semi-erect and erect growth habits, respectively, from the types II were the most competitive with the infesting community of weeds, when compared to bean cultivars type III, since these promote a bigger ground coverage, for they are more branched and prostrate. Machado et al. (2015), in evaluating the bean grain efficiency, IPR Tiziu cultivar, and the economic threshold level under two competition periods with Euphorbia heterophylla, stated that in all simulations the ETL was low: smaller than 3.3 plants $\mathrm{m}^{-2}$.
In all cultivars' average, and comparing the smaller and the bigger grain productivity, a difference in the ETL in the order of $50 \%$ was observed (Figure 5). Thus, the more elevated the productive potential of the cultivars, the smaller the bean plant's population necessary to overcome the ETL will be, making the use of control measures of beggartick noncompensatory. Kalsing and Vidal (2013), while evaluating the economic threshold level for alexander grass (Urochloa plantaginea), it was observed that this also varies due to common bean cultivars seeded and that those with a greater productive potential may present lesser levels of economic threshold.

The average results from all the cultivars when comparing the biggest and smallest price in the bean sacks, it was observed a variation 3.9 times greater in the ETL value (Figure 6). Therefore, the smallest the price paid for the bean sack, the biggest the necessary beggartick's population will be to surpass the ETL and, thereby, compensate the control method.

Regarding the efficiency of the control chemical method with the use of herbicide, it was observed that in the average efficiency (90\%), when comparing with the smallest $(80 \%)$ or the biggest $(100 \%)$, alterations of the ETL of 8 and 13\% are obtained, respectively (Figure 7). Thus, the level of control influences the ETL: the higher the herbicide's efficiency, the lesser the ETL (less beggartick plants

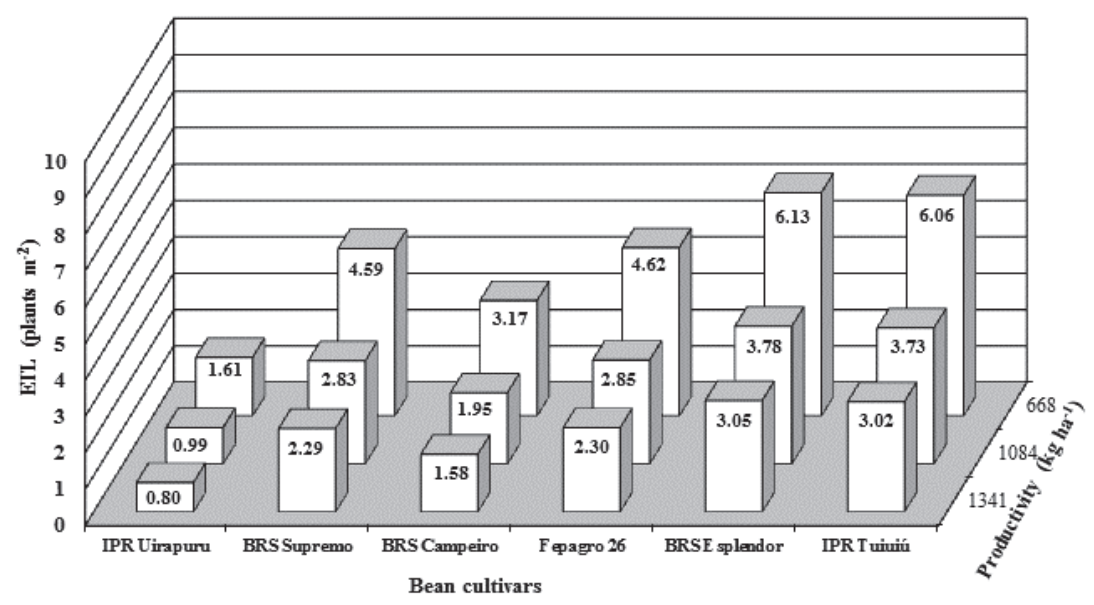

Figure 5 - Economic threshold level (ETL) of beggartick's population to the bean plants related to the productivity of grains in cultivars type black. UFFS, Erechim/RS. 


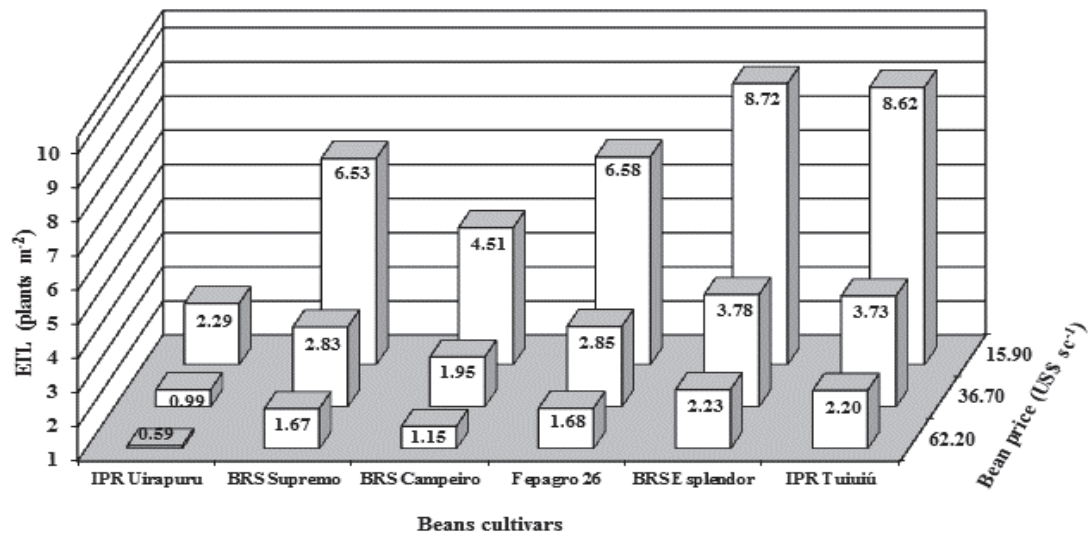

Figure 6 - Economic threshold level (ETL) of beggartick's population to the bean plants related to the beans' price and grains in cultivars type black. UFFS, Erechim/RS.

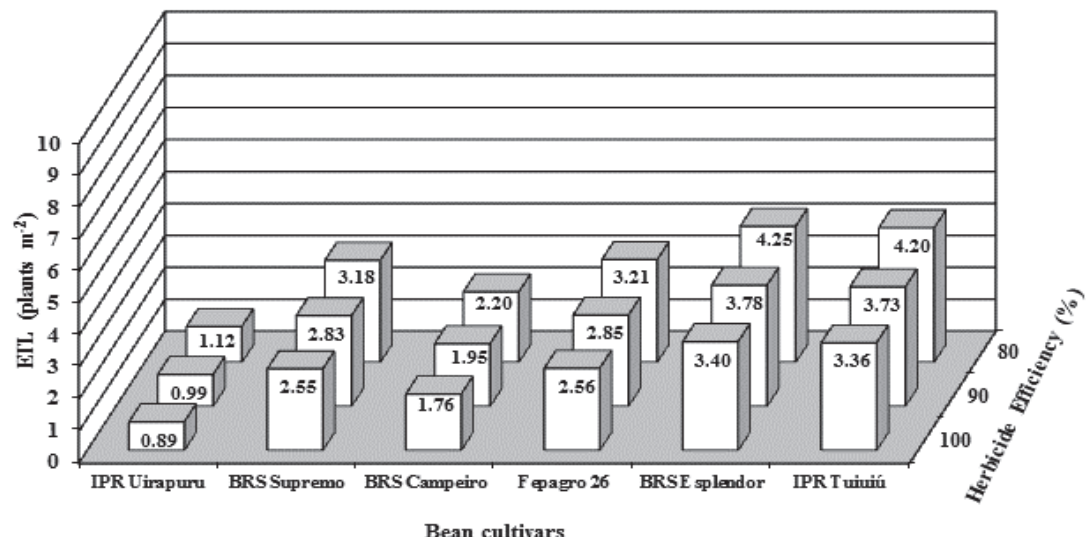

Figura 7 - Economic threshold level (ETL) of beggartick's population to the bean plants related to herbicide efficiency in cultivars type black. UFFS, Erechim/RS.

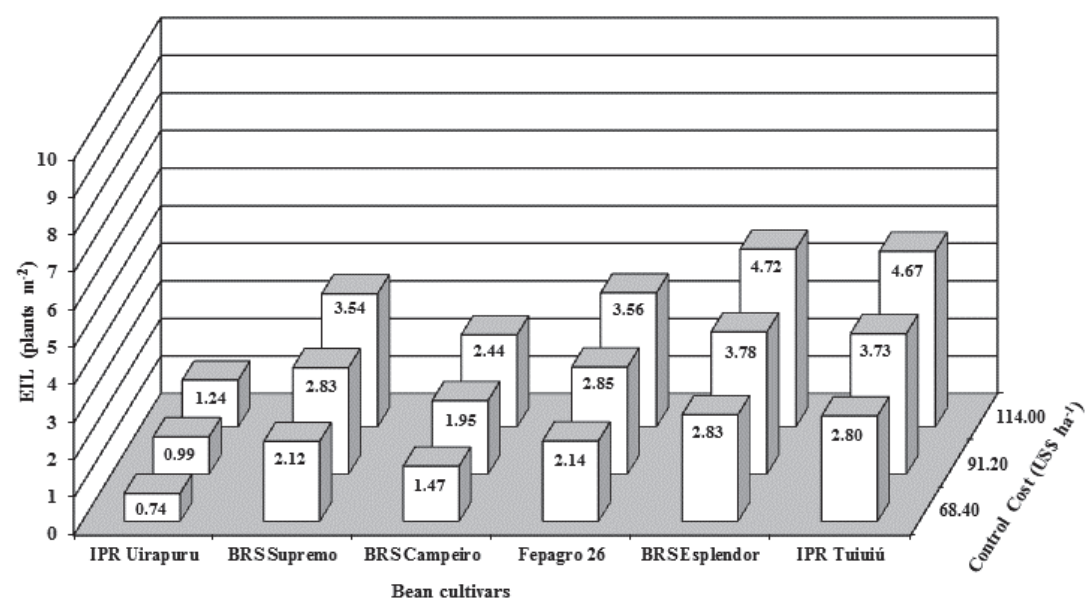

Figura 8 - Economic threshold level (ETL) of beggartick's population to the bean plants related to the control cost in cultivars type black. UFFS, Erechim/RS. 
per $\mathrm{m}^{2}$ needed to adopt control measures), fact also verified by Agostinetto et al. (2010).

In the case of the beggartick's control cost in all the cultivars, the minimum cost was $40 \%$ smaller than the maximum cost. Thus, as bigger the control method cost, the bigger the ETLs, and more beggartick plants per $\mathrm{m}^{2}$ are necessary to justify the control measures (Figure 8). The use of ETL as a management tool for weeds must be associated with good agricultural bean management practices, since its introduction is only justified in crops that make use of crop rotation, appropriate plant arrangement, use of more competitive crops, suited seeding periods, soil fertility correction, among others.

The results obtained allows the conclusion that the nonlinear regression model of the rectangular hyperbola estimates properly the losses in productivity of bean plant grains in the presence of beggartick. The bean cultivars BRS Esplendor, IPR Tuiuiú and Fepagro 26 showed a greater competitive ability with the beggartick than the cultivars BRS Campeiro, BRS Supremo and IPR Uirapuru. The ETL values vary from 0.59 to 6.53 plants $\mathrm{m}^{-2}$ for the cultivars IPR Uirapuru, BRS Supremo and BRS Campeiro, which showed a smaller competitiveness with the beggartick. The biggest ETL values varied between 1.68 and 8.72 plants $\mathrm{m}^{-2}$ for the cultivars Fepagro 26, BRS Esplendor and IPR Tuiuiú, which showed the biggest competitiveness with the beggartick. The ETLs diminish with the increase of grain productivity, price of bean sack and herbicide efficiency, and with the reduction of the cost in the beggartick's control, justifying the adoption of control measures in smaller weed populations.

\section{ACKNOWLEDGEMENTS}

To CNPq and FAPERGS, for the financial support to this research (process n. 482144/ 2012-2/CNPq and 12/2265-3/FAPERGS) and for the scholarships.

\section{REFERENCES}

Agostinetto D. et al. Interferência e nível de dano econômico de capim-arroz sobre o arroz em função do arranjo de plantas da cultura. Planta Daninha. 2010;28:993-1003.

Planta Daninha, Viçosa-MG, v. 34, n. 3, p. 411-422, 2016
Barroso A.A.M., Yamauti M.S., Alves P.L.C.A. Interferência entre especeis de planta daninha e duas cultivares de feijoeiro em duas épocas de semeadura. Bragantia. 2010;69:609-16.

Bauer T.A., Mortensen D.A. A comparison of economic and economic optimum thresholds for two annual weeds in soybeans. Weed Technol. 1992;6:228-35.

Bressanin F.N. et al. Influência da adubação nitrogenada sobre a interferência de plantas daninhas em feijoeiro. Rev Ceres. 2013;60:43-52.

Comissão Técnica Sul-Brasileira de Feijão-CTSBF. Informações técnicas para o cultivo de feijão na Região Sul brasileira. $2^{\mathrm{a}}$.ed. Florianópolis: Epagri, 2012. 157p.

Cousens R. An empirical model relating crop yield to weed and crop density and a statistical comparison with other models. J Agric Sci. 1985;105:513-21.

Dieleman A. et al. Empirical models of pigweed (Amaranthus spp.) interference in soybean (Glycine max). Weed Sci. 1995;43:612-8.

Kalsing A., Vidal R.A. Nível crítico de dano de papuã em feijão-comum. Planta Daninha. 2013;31:843-50.

Lindquist J.L., Kropff M.J. Application of an ecophysiological model for irrigated rice (Oryza sativa) Echinochloa competition. Weed Sci. 1996;44:52-6.

Machado A.B. et al. Rendimento de grãos de feijão e nível de dano econômico sob dois períodos de competição com Euphorbia heterophylla. Planta Daninha. 2015;33:41-8.

Parreira M.C. et al. Comparação entre métodos para determinar o período anterior à interferência de plantas daninhas em feijoeiros com distintos tipos de hábitos de crescimento. Planta Daninha. 2014;32:727-38.

Ratkowsky D.A. Nonlinear regression modeling: a unified practical approach. New York: Marcel Dekker, 1983. p.13554.

Santos J.B., Cury J.P. Picão-preto: uma planta daninha especial em solos tropicais. Planta Daninha. 2011;29:115971.

Swinton S.M. et al. Estimation of crop yield loss due to interference by multiple weed species. Weed Sci.

1994;42:103-9.

Tavares C.J. et al. Fitossociologia de plantas daninhas na cultura do feijão. Rev Bras Cienc Agr. 2013;8:27-32.

Vidal R.A., Kalsing A., Gherekhloo J. Interferência e nível de dano econômico de Brachiaria plantagiea e Ipomoea nil na cultura do feijão comum. Ci Rural. 2010;40:1675-81. 